\title{
INTERSEX AND LIVER ALTERATIONS INDUCED BY LONG-TERM SUBLETHAL EXPOSURE TO $17 \alpha$-ETHINYLESTRADIOL IN ADULT MALE CNESTERODON DECEMMACULATUS (PISCES: POECILIIDAE)
}

\author{
Brian Jonathan Young, $\dagger$ Gabriela Carina López, $\ddagger$ Diego Sebastián Cristos, $§$ Diana Cristina Crespo, $\dagger$ \\ Gustavo Manuel Somoza, $\ddagger$ and Pedro Carriquiriborde*\| \\ $\nmid$ †aboratorio de Transformación de Residuos, Instituto de Microbiología y Zoología Agrícola, Instituto Nacional de Tecnología Agropecuaria, \\ Castelar, Buenos Aires, Argentina

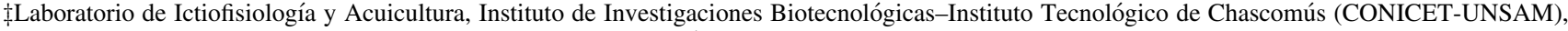 \\ Chascomús, Buenos Aires, Argentina \\ $\S$ Laboratorio de Contaminantes Químicos, Instituto de Tecnología de Alimentos, Instituto Nacional de Tecnología Agropecuaria, Castelar, \\ Buenos Aires, Argentina \\ \|Centro de Investigaciones del Medio Ambiente, Departamento de Química, Universidad Nacional de La Plata, CONICET, La Plata, \\ Buenos Aires, Argentina
}

(Submitted 26 February 2016; Returned for Revision 27 March 2016; Accepted 4 July 2016)

\begin{abstract}
The aim of the present study was to assess the responses of the gonopodium morphology and the gonadal and liver histology of adult male Cnesterodon decemmaculatus to sublethal long-term exposure concentrations of $17 \alpha$-ethinylestradiol (EE2). Two experiments were conducted exposing the fish to waterborne concentrations of EE2 ranging from $20 \mathrm{ng} / \mathrm{L}$ to $200 \mathrm{ng} / \mathrm{L}$ for $8 \mathrm{wk}, 12 \mathrm{wk}$, and 16 wk. Intersex gonads were observed after $8 \mathrm{wk}$ and $16 \mathrm{wk}$ in fish exposed to $200 \mathrm{ng}$ EE2/L and $100 \mathrm{ng}$ EE2/L, respectively. Oocytes' development from testis germ cells and replacement of the efferent duct periodic acid-Schiff-positive secretion surrounding spermatozeugmata by parenchymal tissue and duct structure alterations were the major observed changes in the gonads. In contrast, no response was observed in the gonopodium morphology. Liver histology was also altered, showing increasing steatosis, single-cell necrosis to generalized necrosis, and disruption of acinar organization from $100 \mathrm{ng}$ EE2/L to $200 \mathrm{ng}$ EE2/L. In summary, the present results showed that although EE2 was not able to alter the morphology of a developed gonopodium, it was capable of inducing development of testicular oocytes in adult male $C$. decemmaculatus at environmentally relevant concentrations. Thus, externally normal but intersex $C$. decemmaculatus males would be expected in the wastewater-receiving streams that the species inhabits. According to the literature, the present study would be the first indicating estrogen-induced intersex in adult male poeciliid. Environ Toxicol Chem 2017;36:1738-1745. (C) 2016 SETAC
\end{abstract}

Keywords: Ecotoxicology Estrogenic compounds Testis-ova Hepatotoxicity Cnesterodon decemmaculatus

\section{INTRODUCTION}

More than 2 decades of research has shown that endocrinedisrupting chemicals (EDCs) are an issue of environmental concern because they are able to induce widespread damage in the aquatic environment. In particular, $17 \alpha$-ethinylestradiol (EE2) is a potent xenoestrogen considered to be a serious threat to wildlife and fisheries [1]. Concentrations as low as $5 \mathrm{ng} / \mathrm{L}$ have been able to collapse complete fish populations [2]. As a result of its environmental relevance and its well-known mode of action via estrogen receptors-mediated pathways, EE2 has been broadly adopted as an EDC model to assess estrogenic effects in fish bioassays [3].

Fish traditionally have been used for assessing the impact of EDCs because basic aspects of the hypothalamic-pituitarygonadal axis are significantly conserved across vertebrates [4]. In particular, small fish species have been broadly adopted as model organisms [5], and development of toxicity testing for ecological risk assessment of EDCs has been recommended by international organizations [6]. Poeciliid fish, in particular, have been proposed as valuable indicators of exposure to EDCs because they exhibit hormone-dependent sexual dimorphism. In

\footnotetext{
* Address correspondence to pcarriquiriborde@gmail.com

Published online 6 July 2016 in Wiley Online Library

(wileyonlinelibrary.com).

DOI: $10.1002 /$ etc. 3547
}

this fish family, the male anal fin is modified into a gonopodium and used to transfer sperm during copulation. It is known that gonopodium development is dependent on androgens [7], and several studies have demonstrated that it is susceptible to alteration by exposure to both androgens and estrogens. Androgens elongate and thicken rays of the anal fin in females $[8,9]$, whereas estrogens shorten total length and reduce elongation of the gonopodium in males; however, these responses differ depending on developmental stage [10,11]. In addition, it has been shown that EDCs can also affect the gonad and the liver histology of poeciliids $[12,13]$.

Cnesterodon decemmaculatus is a neotropical poeciliid widely distributed in the freshwater ecosystems of Argentina, Brazil, Uruguay, and Chile and belongs to the same family as the genera Gambusia, Xiphophorus, and Poecilia [14]. This small, nonmigratory fish is abundant in vegetated ponds and streams, even under moderately polluted conditions. It is a gonochoric, dimorphic, and ovoviviparous species. Females are larger than males, and the male anal fin is modified into a gonopodium. The life span is relatively short (2-4yr), reaching sexual maturity after 3 mo. Females produce between 10 and 25 live young several times during the reproductive season. This species is easy to maintain in the laboratory, and under this condition, it is possible to produce offspring almost year-round. In recent years, $C$. decemmaculatus also has been used frequently for ecotoxicological studies, both in the laboratory [15] and in the 
field [16]. Although the basic gonadal histology and gonopodium morphology of $C$. decemmaculatus have been described previously $[17,18]$, the response of this species to EDCs has not been assessed.

In this context, the aim of the present study was to evaluate the responses of the gonopodium morphology and the gonadal and liver histology of adult male $C$. decemmaculatus after longterm exposures to sublethal concentrations of the model xenoestrogen EE2. This was the first step toward characterizing the response of this species as a potential regional model for testing endocrine disruption.

\section{MATERIALS AND METHODS}

\section{Experimental design and conditions}

Two experiments were conducted. Experiment 1 was run as a preliminary trial. Three concentrations (0 ng EE2/L, $20 \mathrm{ng}$ $\mathrm{EE} 2 / \mathrm{L}$, and $200 \mathrm{ng} \mathrm{EE} 2 / \mathrm{L}$ ) and 2 exposure times (8 wk and $12 \mathrm{wk})$ were tested without replicates. Fifteen adult male fish (17.6-22.3 mm, total length) were allocated to each treatment. Experiment 2 was handled as a definitive trial. Four concentrations $(0 \mathrm{ng} / \mathrm{L}, 20 \mathrm{ng} / \mathrm{L}, 100 \mathrm{ng} / \mathrm{L}$, and $200 \mathrm{ng} / \mathrm{L})$ and 2 exposure times ( $8 \mathrm{wk}$ and $16 \mathrm{wk}$ ) were tested. The 8 treatments were randomly assigned by duplicate to each of 16 tanks containing 16 adult male fish $(16.9-25.9 \mathrm{~mm}$, total length). The tested concentrations were established, starting from environmentally relevant levels reported for Argentina [19] to sublethal levels just below lethal concentrations, for assessing response capability of selected endpoints. Exposure times were set, taking into account the facts that changes in studied histological variables usually take weeks to become evident, that sewage discharges are continuous, and that downstream small, nonmigratory fish are exposed for long periods.

Adult male $C$. decemmaculatus used for experiments were obtained from broodstock maintained at the aquarium facilities of the Instituto Nacional de Tecnología Agropecuaria (INTA), Castelar, Buenos Aires, Argentina. Fish were handled following the principles and procedures approved by the INTA Institutional Committee for the Care and Use of Experimental Animals.

The EE2 (Parafarm ${ }^{\circledR} 99 \%$ purity; Saporiti) stock and working solutions were prepared in absolute ethanol (Biopack) and stored at $-20{ }^{\circ} \mathrm{C}$ until use. Testing concentrations were freshly prepared before each media renewal by diluting appropriate aliquots of the working solution in dilution media. Dechlorinated tap water stabilized with gentle aeration was used as dilution media ( $\mathrm{pH}, 8.6 \pm 0.1$; conductivity, $720 \pm 3 \mu \mathrm{S} / \mathrm{cm}$ ). Ethanol concentration was established at $0.0025 \%$ in all treatments, including the control aquaria.

Experiments were conducted under controlled laboratory conditions in an acclimatized room $\left(22 \pm 2{ }^{\circ} \mathrm{C}\right)$ setting with a 16:8-h light:dark photoperiod. The experiments were conducted using 3-L glass aquaria under static-flow conditions with $100 \%$ media renewal every $48 \mathrm{~h}$. Fish were fed daily ad libitum with commercial Fish Food Flakes (Shulet ${ }^{\mathrm{B}}$ ). Debris was siphoned from the bottom of the testing chambers before media renewal. Wastes were adequately disposed of before subsequent treatment by a hazardous-waste treatment company.

\section{Fish mortality and condition}

In both experiments, the number of dead fish per treatment was recorded every day, and dead fish were removed from the testing chambers. At each sampling time, standard length of icewater anesthetized fish was measured using a digital caliper
$( \pm 0.1 \mathrm{~mm})$. In experiment 2 , weight was also measured using a digital scale $( \pm 0.1 \mathrm{mg})$, and condition factor was calculated as (weight $[\mathrm{mg}] /$ standard length $\left.^{3}[\mathrm{~mm}]\right) \times 100$. $^{2}$

\section{Gonopodium morphology}

The gonopodium morphology was observed under a stereomicroscope (Leica GZ6). The lengths of the fourth (R4) and sixth (R6) fin rays were measured. The length of the ray was defined as the length from the origin of the anal fin to the tip of the ray [11]. Two indexes were used as morphological endpoints: the elongation index and the gonopodial index. The elongation index and the gonopodial index were calculated as the R4/R6 ratio and the ratio of $(\mathrm{R} 4 \times 100) /$ standard length, respectively [8]. Standard length, R4, and R6 were measured using an electronic digital caliber (precision of $0.1 \mathrm{~mm}$; Schwyz). The bony and cartilaginous structures were observed using an in toto staining with Alizarin Red and Alcian Blue (Biopack), according to Chalde et al. [20]. The anal fin morphology was photographed with a digital camera (Evolution BF) attached to a stereomicroscope (Nikon SMZ800). Pictures were processed using the software Image-Pro Plus Ver 4.5.

\section{Histology}

Tissues were fixed in Bouin's fluid, dehydrated, and embedded in paraffin. Samples were serially sectioned every $60 \mu \mathrm{m}$ and stained with either hematoxylin-eosin or periodic acid-Schiff (PAS). The preparations were examined and photographed with a light microscope (Nikon Eclipse E600) equipped with a digital camera (Nikon DS-Fi1). Pictures were processed using the software NIS-Elements F 3.00.

Quantitative histological endpoints were assessed only at the end of experiment 2. In the gonads, the evaluated endpoints were the percentage of fish presenting testis-ova, the median percentage of histological sections with presence of oocytes in fish with testis-ova, and the median number of oocytes per testis in fish with testis-ova. The whole gonad was assessed, and only those oocytes presenting the nucleus were considered, to avoid double counting. In the liver, the histological changes were quantified following the method proposed by Bernet et al. [21] for calculating the organ index $\left(I_{\text {org }}\right)$, as a standardized way to quantify organ damage

$$
I_{\text {org }}=\sum_{r p} \sum_{\text {alt }}\left(a_{\text {org rp alt }} \times w_{\text {org rp alt }}\right)
$$

where $\operatorname{org}$ is the organ (liver); $r p$ is the reaction patterns; alt is the alteration; $a$ is the importance factor, which takes the values of 1,2 , or 3 indicating minimal, moderate, or marked pathological importance, respectively; and $w$ is the score, which has the values of $0,2,4$, or 6 for unchanged, mild, moderate, or severe occurrence, respectively.

\section{Analysis of waterborne EE2 concentration}

The EE2 actual concentrations in the testing media during the experiments were measured by liquid chromatographytandem mass spectrometry, according to Valdes et al. [19]. Briefly, $250 \mathrm{~mL}$ of testing media was filtered through a $0.45-\mu \mathrm{m}$ nylon membrane, extracted using a 200-mg C-18 SPE (Oasis HLB; Waters), and eluted with methanol. Extracts were dried out under a gentle nitrogen stream and resuspended in $250 \mu \mathrm{L}$ of methanol before being analyzed by high-performance liquid chromatography coupled to tandem mass spectrometry using a Thermo Scientific Surveyor ${ }^{\text {TM }}$ LC system coupled with a Thermo Scientific LTQ XL Linear Ion Trap equipped with an 
electrospray ionization source operated in negative mode. Chromatographic separation was accomplished on a C-18 column (Thermo BDS Hypersil, $3 \mu \mathrm{m}, 150 \mathrm{~mm} \times 4.6 \mathrm{~mm}$; Thermo Fisher Scientific) using an aqueous formic acid $(0.1 \%) /$ methanol gradient $(85-100 \%$ in $15 \mathrm{~min}$ at $0.3 \mathrm{~mL} / \mathrm{min}$ flow rate) as mobile phase. The precursor ion for EE2 was identified as the deprotonated molecule $\mathrm{m} / z, 295.25$, and the product ions were $m / z, 267.17$ and $m / z, 262.25$. The $m / z, 267.17$ value was used for quantification according to the external standard method against a 5-point calibration curve. Recovery was estimated by spiking the testing media samples with $10 \mu \mathrm{g} / \mathrm{L}$ of $\left[{ }^{13} \mathrm{C}\right] \mathrm{EE} 2$ stable isotope (99\% purity; Cambridge Isotope Laboratories). The percentage of recovery was $65 \%$, and the detection and quantification limits were $5 \mathrm{ng} / \mathrm{L}$ and $17 \mathrm{ng} / \mathrm{L}$, respectively.

\section{Data analysis}

Analysis of variance (ANOVA) was used for testing statistically significant differences $(p<0.05)$ induced by EE2 treatment on length, weight, condition factor, R4, R6, elongation index, gonopodial index, and organ index after testing assumptions of normality and homoscedasticity using the Shapiro-Wilk test and Levene's test, respectively. When significant effects were observed, the Tukey honest significant test for post hoc comparisons was used to calculate statistical differences among treatment groups. The $\chi^{2}$ contingency test was used for the comparison of percentages and frequencies. Because the assessed gonad histological endpoints were not normally distributed, they were then analyzed using the median test. The lowest-observed-effect concentration (LOEC) and noobserved-effect concentration (NOEC) were estimated from the lowest and highest tested concentration showing, or not showing, significant differences with respect to the control group, respectively. All analyses were performed using the Prism $5{ }^{\circledR}$ for Windows (GraphPad Software).

\section{RESULTS}

Although some variations in the EE2 concentrations were observed in water samples taken after testing media renewal, the overall mean of the measured concentrations was between $88 \%$ and $113 \%$ of the nominal value (Table 1). No EE2 was detected in any of the control recipients during the exposure period.
Table 1. EE2 concentrations measured in test media for experiment $2^{\mathrm{a}}$

\begin{tabular}{lc}
\hline Nominal concentration $(\mathrm{ng} / \mathrm{L})$ & Measured concentrations $(\mathrm{ng} / \mathrm{L})$ \\
\hline Control & ND \\
20 & $21.1 \pm 11.5(4)$ \\
100 & $113.1 \pm 8.8(4)$ \\
200 & $176.1 \pm 3.2(4)$ \\
\hline
\end{tabular}

${ }^{\mathrm{a}}$ Measured concentrations are presented as the mean \pm standard deviation $(n$ in parentheses)

$\mathrm{EE} 2=17 \alpha$-ethinylestradiol; $\mathrm{ND}=$ no detectable levels

\section{Mortality, condition factor, and gonopodium morphology}

Mortality at the end of both experiments ranged between $12.5 \%$ and $21.9 \%$, and no statistical differences were found between any EE2 treatment group and the control group. Standard length was not affected by EE2 exposure. In experiment 2, weight was found to increase with the EE2 exposure, but differences were not statistically significant. However, significant effect induced by EE2 (ANOVA, $p=0.043$ ), following a dose-response relationship, was observed in the condition factor (Table 2). It was significantly higher in fish exposed to $200 \mathrm{ng} / \mathrm{L}$ in weeks 8 and 16 and in fish exposed to $100 \mathrm{ng} / \mathrm{L}$ in week 16 (Table 2).

The bony and cartilaginous structure of the gonopodium of a mature male is shown in Figure 1. All adult males used in the experiments presented a fully developed gonopodium with hook, serrae, and cirrus. None of the assessed morphological parameters or the calculated gonopodium indexes was affected by EE2 exposure.

\section{Gonadal histology}

Illustrative pictures of testis histology in control and EE2treated adult male $C$. decemmaculatus are shown in Figure 2. No differences were observed in either of the 2 experiments between fish in the control group and those in the $20 \mathrm{ng} / \mathrm{L}$ group (Figure 2A and B), and the histological features were the same as previously described for a mature adult male by Parenti et al. [18]. Testes were located in the midline of the body cavity and fused as a single organ. The center of the organ was dominated by spermatozeugmata (naked sperm bundles) immersed in a PAS-positive substance. In this gonadal stage,

Table 2. Summary of mortality, fish length, weight, condition factor, and gonopodium morphological parameters and indexes for adult male Cnesterodon decemmaculatus at the end of experiments 1 and $2^{\mathrm{a}}$

\begin{tabular}{|c|c|c|c|c|c|c|c|c|c|c|}
\hline \multirow[b]{2}{*}{ Treatment } & \multirow[b]{2}{*}{ Replicates } & \multicolumn{9}{|c|}{ Parameter } \\
\hline & & $n$ & Mortality (\%) & $\mathrm{SL}(\mathrm{mm})$ & W (mg) & $K$ & $\mathrm{R} 4(\mathrm{~mm})$ & $\mathrm{R} 6$ (mm) & GI $(\%)$ & EI \\
\hline Control & $\mathrm{A}$ & 15 & 13.3 & $20.1 \pm 1.3$ & NA & NA & $8.32 \pm 0.97$ & $3.58 \pm 0.57$ & $41.4 \pm 2.91$ & $2.34 \pm 0.18$ \\
\hline $20 \mathrm{ng} / \mathrm{L}$ & A & 15 & 20.0 & $20.9 \pm 1.2$ & NA & NA & $8.15 \pm 0.52$ & $3.53 \pm 0.35$ & $39.1 \pm 2.15$ & $2.33 \pm 0.12$ \\
\hline $200 \mathrm{ng} / \mathrm{L}$ & A & 15 & 26.7 & $20.9 \pm 1.3$ & NA & NA & $8.44 \pm 0.70$ & $3.57 \pm 0.39$ & $40.3 \pm 2.13$ & $2.37 \pm 0.11$ \\
\hline $20 \mathrm{ng} / \mathrm{L}$ & $\begin{array}{l}\mathrm{A} \\
\mathrm{B}\end{array}$ & $\begin{array}{l}16 \\
16\end{array}$ & $18.8 \pm 8.8$ & $21.4 \pm 0.4$ & $137.7 \pm 1.3$ & $1.38 \pm 0.06$ & $8.60 \pm 0.14$ & $4.02 \pm 0.03$ & $40.3 \pm 0.14$ & $2.15 \pm 0.07$ \\
\hline $100 \mathrm{ng} / \mathrm{L}$ & $\begin{array}{l}\mathrm{A} \\
\mathrm{B}\end{array}$ & $\begin{array}{l}16 \\
16\end{array}$ & $15.7 \pm 4.5$ & $20.6 \pm 0.6$ & $139.4 \pm 6.0$ & $1.51 \pm 0.04^{*}$ & $8.55 \pm 0.07$ & $3.85 \pm 0.07$ & $40.6 \pm 0.28$ & $2.23 \pm 0.04$ \\
\hline 200 ng/L & $\begin{array}{l}\text { A } \\
\text { B }\end{array}$ & $\begin{array}{l}16 \\
16\end{array}$ & $15.7 \pm 4.5$ & $21.7 \pm 0.3$ & $153.0 \pm 3.2$ & $1.46 \pm 0.01 *$ & $8.55 \pm 0.07$ & $4.02 \pm 0.03$ & $39.4 \pm 0.57$ & $2.13 \pm 0.04$ \\
\hline
\end{tabular}

${ }^{\mathrm{a}}$ Values are presented as the mean \pm standard deviation.

*Significantly different from controls $(p<0.05)$.

$n=$ number of fish per replicate; $\mathrm{SL}=$ standard length; $\mathrm{W}=$ body weight; $K=$ condition factor; $\mathrm{R} 4$ and $\mathrm{R} 6=$ fin rays; $\mathrm{GI}=$ gonopodium index $([\mathrm{R} 4 \times 100] / \mathrm{SL})$; $\mathrm{EI}=$ elongation index $(\mathrm{R} 4 / \mathrm{R} 6) ; \mathrm{NA}=$ not assessed. 


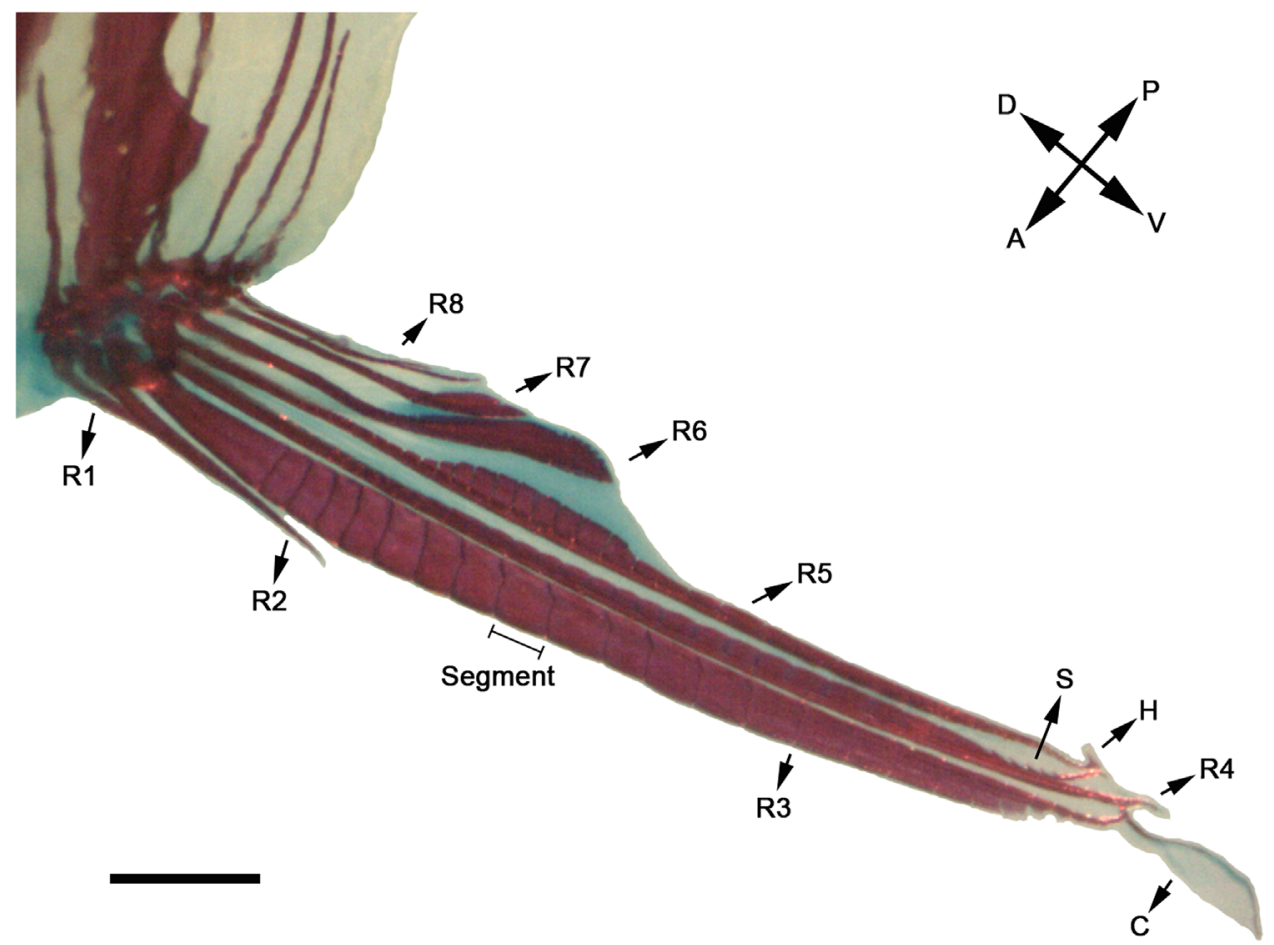

Figure 1. Anal fin of a representative control male Cnesterodon decemmaculatus stained in toto. The bony and cartilaginous structures were stained in Alizarin Red and Alcian Blue, respectively. Fin ray $(\mathrm{R})$ numeration increases in ventral-dorsal direction. The scale bar represents $1 \mathrm{~mm}$. $\mathrm{A}=$ anterior; $\mathrm{P}=$ posterior; $\mathrm{V}=$ ventral; $\mathrm{D}=$ dorsal $; \mathrm{S}=$ serrae $; \mathrm{H}=$ hook $\mathrm{C}=$ cirrus.

the spermatogonia and spermatids were organized into cysts, restricted to the periphery of the testes. In contrast, dose-response effects were observed for all other EE2 concentrations, mainly characterized by the induction of testis-ova and testis histoarchitecture alterations. In an early stage of alteration, a few primary oocytes were developed in the edges of the fused testes (Figure 2C and D). This phase was characteristic of fish exposed to $100 \mathrm{ng} / \mathrm{L}$ and $200 \mathrm{ng} / \mathrm{L}$ for $8 \mathrm{wk}$ or to $100 \mathrm{ng} / \mathrm{L}$ for $16 \mathrm{wk}$. An intermediate stage was characterized by the increase of the number of peripheral oocytes and cysts with immature stages (undifferentiated gonia, spermatocytes, and spermatids), as well as the development of interstitial cells around spermatozeugmata replacing the PAS-positive secretion (Figure 2E and F). Such changes were observed in all fish exposed to $200 \mathrm{ng} / \mathrm{L}$ during $12 \mathrm{wk}$ and in some fish exposed to that concentration during $16 \mathrm{wk}$. The most advanced stage of alteration observed was characterized by an even greater number of oocytes, occupying a more central section of the testis, a marked decrease in the number of spermatozeugmata, together with the changes mentioned above, plus hyperplasia of the duct epithelium. These changes were observed only in fish exposed to $200 \mathrm{ng} / \mathrm{L}$ for 16 wk (Figure 2G and $\mathrm{H}$ ).

The results of quantitative histological analysis in the gonads are shown in Figure 3. The percentage of fish presenting testisova after $16 \mathrm{wk}$ was significantly different with respect to controls from fish exposed to $100 \mathrm{ng} / \mathrm{L}$ (Figure 3A). The same differences were observed earlier, from week 8 in fish exposed to $100 \mathrm{ng} / \mathrm{L}$ in experiment 2 , and $200 \mathrm{ng} / \mathrm{L}$ in experiment 1 , presenting $20 \%$ and $40 \%$ of intersex fish, respectively (data not shown in the figure). The percentage of fish with testis-ova was increased from week 8 to week 16 and was higher in $200 \mathrm{ng} / \mathrm{L}$ than in $100 \mathrm{ng} / \mathrm{L}$ in week 8 , but these differences disappeared by week 16. Despite that, the number of oocytes per testis was significantly increased with the dose even at week 16 (Figure 3B and C).

\section{Liver histology}

In the liver, EE2-induced alterations were equivalent in both experiments. Illustrative pictures of liver histology in control and EE2-treated adult male $C$. decemmaculatus are shown in Figure 4. No significant differences from the control group were observed in those fish exposed to $20 \mathrm{ng}$ EE2/L for any exposure time (Figure 4A and B). On the other hand, several histological alterations were found in fish exposed to $100 \mathrm{ng}$ EE2/L and $200 \mathrm{ng}$ EE2/L. Increased hepatocyte intracellular lipid retention (macrovesicular steatosis) and single-cell necrosis, characterized by cells with brightly acidophilic cytoplasm and pyknotic or even absent nucleus [22], were characteristic in the liver of fish exposed to $100 \mathrm{ng} / \mathrm{L}$ after $16 \mathrm{wk}$ (Figure 4C and D). Marked steatosis together with cystic degeneration (i.e., spongiosis hepatis) [23], characterized by multiloculated cysts lined by fine septa filled with a flocculent eosinophilic material and the consequent disruption of the acinar organization, were major alterations observed in fish exposed to $200 \mathrm{ng} / \mathrm{L}$ for $16 \mathrm{wk}$ (Figure 4E and F).

The liver organ index (Figure 5) was significantly affected by EE2 exposure (ANOVA, $p<0.001$ ). However, it was significantly higher than controls only for fish exposed to $200 \mathrm{ng} / \mathrm{L}$ after 16 wk (Tukey, $p<0.001$ ).

\section{Ecotoxicological endpoints}

The NOEC and LOEC values estimated from the condition factor, the gonadal histology, and the liver organ index are shown in Table 3. From the assessed endpoints, the percentage of fish with testis-ova was the most sensitive variable, responding earlier ( $8 \mathrm{wk}$ ) and at lower concentration $(100 \mathrm{ng} / \mathrm{L})$. Longer exposure time was needed for condition 


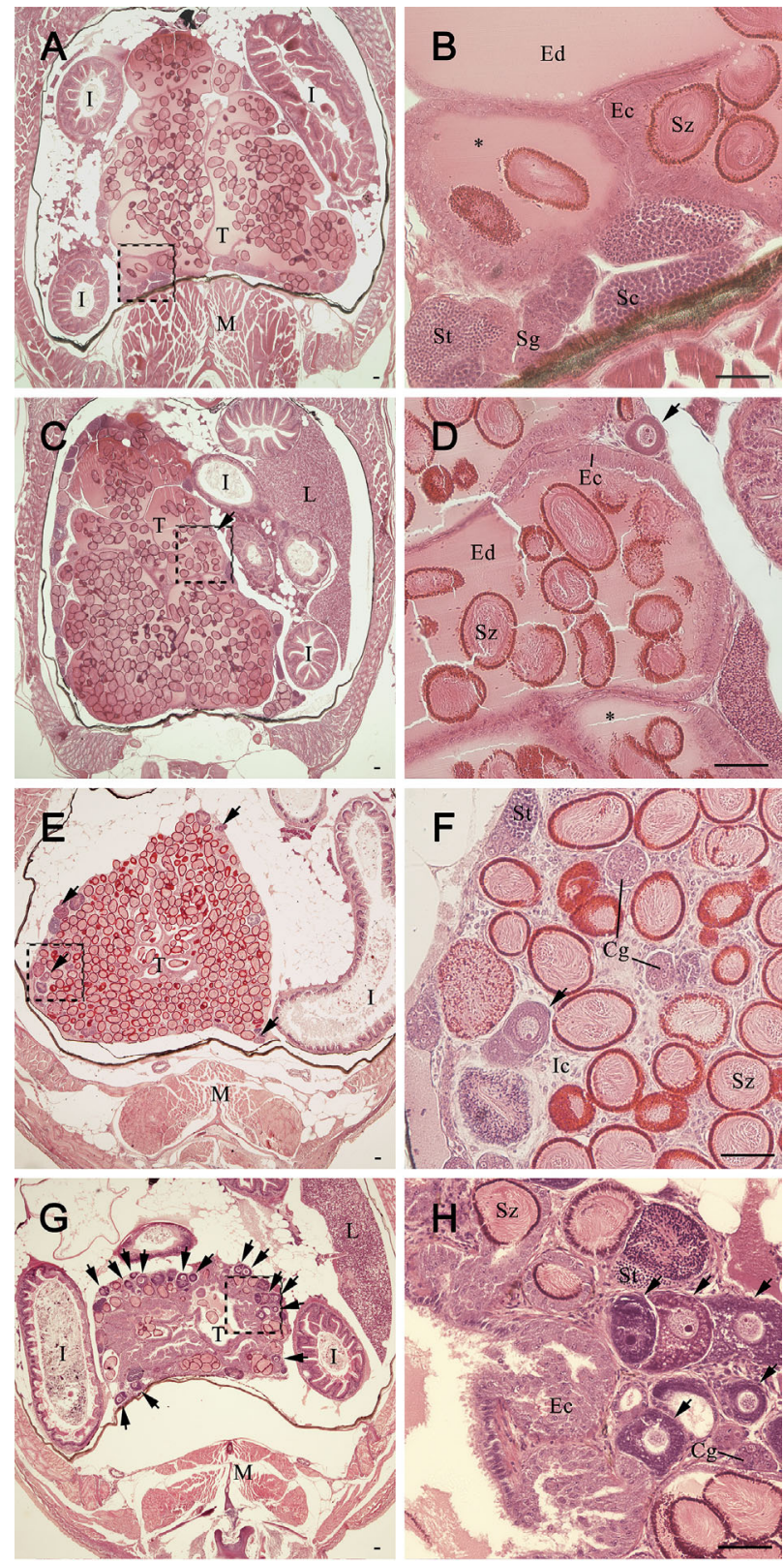

Figure 2. Illustrative images with hematoxylin-eosin staining of testicular histology from adult male Cnesterodon decemmaculatus in control and tested $17 \alpha$-ethinylestradiol (EE2) treatments: $(\mathbf{A}, \mathbf{B})$ control $(0 \mathrm{ng} / \mathrm{L})$ and $20 \mathrm{ng} / \mathrm{L}$ groups after $16 \mathrm{wk}$; (C,D) $100 \mathrm{ng} / \mathrm{L}$ after $8 \mathrm{wk}$ and $16 \mathrm{wk}$, or $200 \mathrm{ng} /$ $\mathrm{L}$ after $8 \mathrm{wk} ;(\mathbf{E}, \mathbf{F}) 200 \mathrm{ng} / \mathrm{L}$ after $12 \mathrm{wk}$ or $16 \mathrm{wk} ;(\mathbf{G}, \mathbf{H})$ only $200 \mathrm{ng} / \mathrm{L}$ after 16 wk. Dashed squares in panels $(\mathbf{A}),(\mathbf{C}),(\mathbf{E})$, and $(\mathbf{G})$ represent enlarged areas in $(\mathbf{B}),(\mathbf{D}),(\mathbf{F})$, and $(\mathbf{H})$. Arrowheads indicate primary oocytes. Asterisks $(*)$ identify periodic acid-Schiff (PAS)-positive secretion. The scale bar represents $50 \mu \mathrm{m}$. $\mathrm{T}=$ testis; $\mathrm{I}=$ intestine; $\mathrm{M}=$ muscle; $\mathrm{L}=$ liver; $\mathrm{Cg}=$ cyst of gonia; $\mathrm{Sc}=$ spermatocytes; $\mathrm{Sg}=$ spermatogonia; $\mathrm{St}=$ spermatids; $\mathrm{Sz}=$ spermatozeugmata; $\mathrm{Ed}=$ efferent duct; $\mathrm{Ec}=$ epithelial cells from efferent duct; $\mathrm{Ic}=$ interstitial cells.

factor to respond at the same concentration, and the liver organ index was significantly different only at $200 \mathrm{ng} / \mathrm{L}$, despite the fact that some histological alterations composing the index (e.g., steatosis) started to change at $100 \mathrm{ng} / \mathrm{L}$.

\section{DISCUSSION}

Because of the conspicuous sexual dimorphism, poeciliids have been broadly used worldwide for assessing effects of ECDs. However, South American species have scarcely been
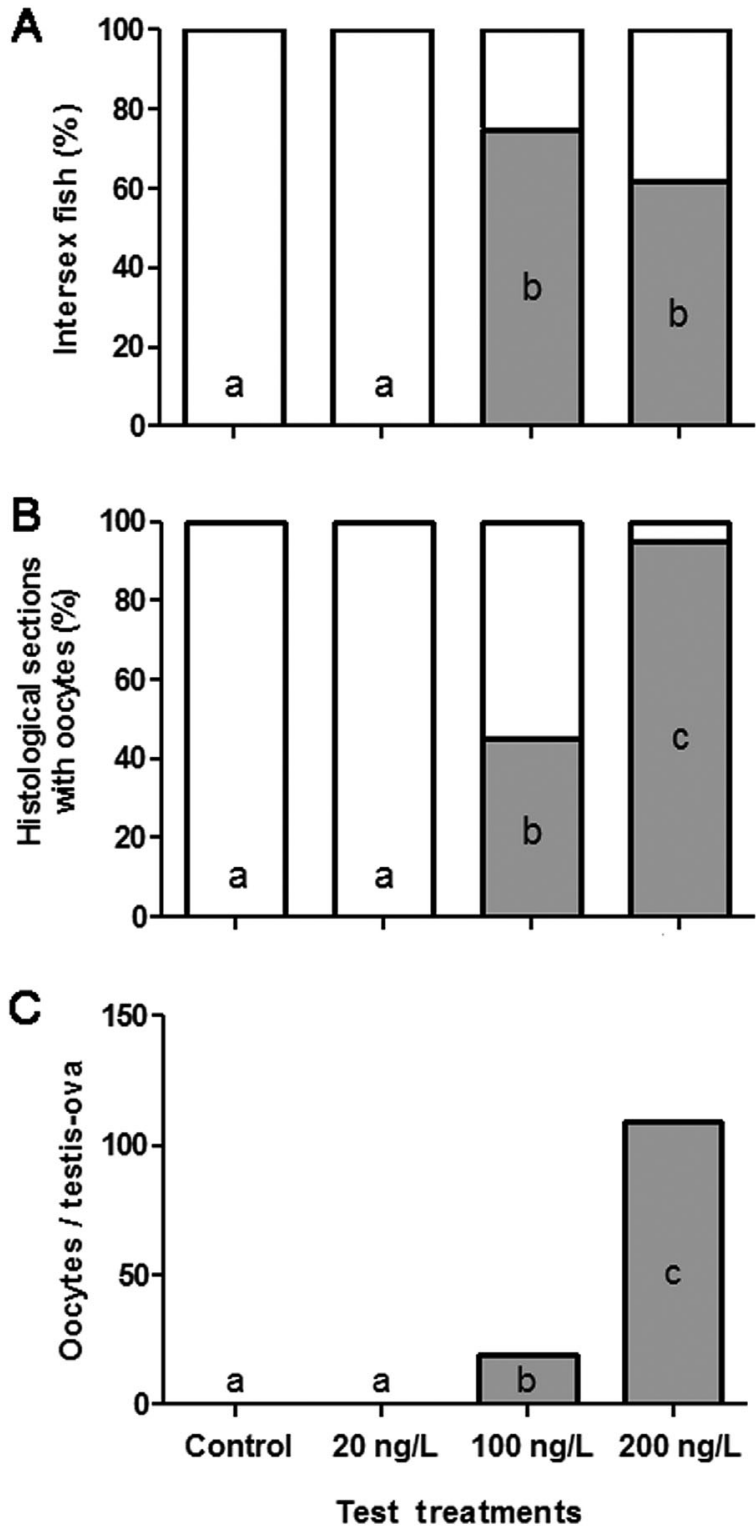

$\square$ Normal testis $\square$ Testis-ova

Figure 3. Percentage of intersex fish and quantitative gonad histological changes observed in adult male Cnesterodon decemmaculatus exposed to $17 \alpha$-ethinylestradiol (EE2) for 16 wk (experiment 2): (A) percentage of intersex fish at each test treatment; (B) percentage of histological sections with presence of oocytes in fish with testis-ova; (C) number of oocytes per fish with testis-ova. Values are presented as the median. Statistical differences among treatments (median test, $p<0.05$ ) are indicated with different letters.

explored for assessing such effects, and their sensitivity to EDCs is unknown. In the present study, the responses of the gonopodium, gonad, and liver of adult male C. decemmaculatus were assessed against waterborne exposure to a xenoestrogen model, across concentrations of toxicological and environmental interest.

The EE2-induced development of testis-ova in adult males was the most significant finding. It was noticed as a time- and concentration-response process that gradually proceeded from the appearance of few oocytes at the edges of the testis to the alteration of the entire histoarchitecture of the gonad, including not only the gametes but also the interstitial and duct cells, and probably eliciting an eventual reproductive disability for the 

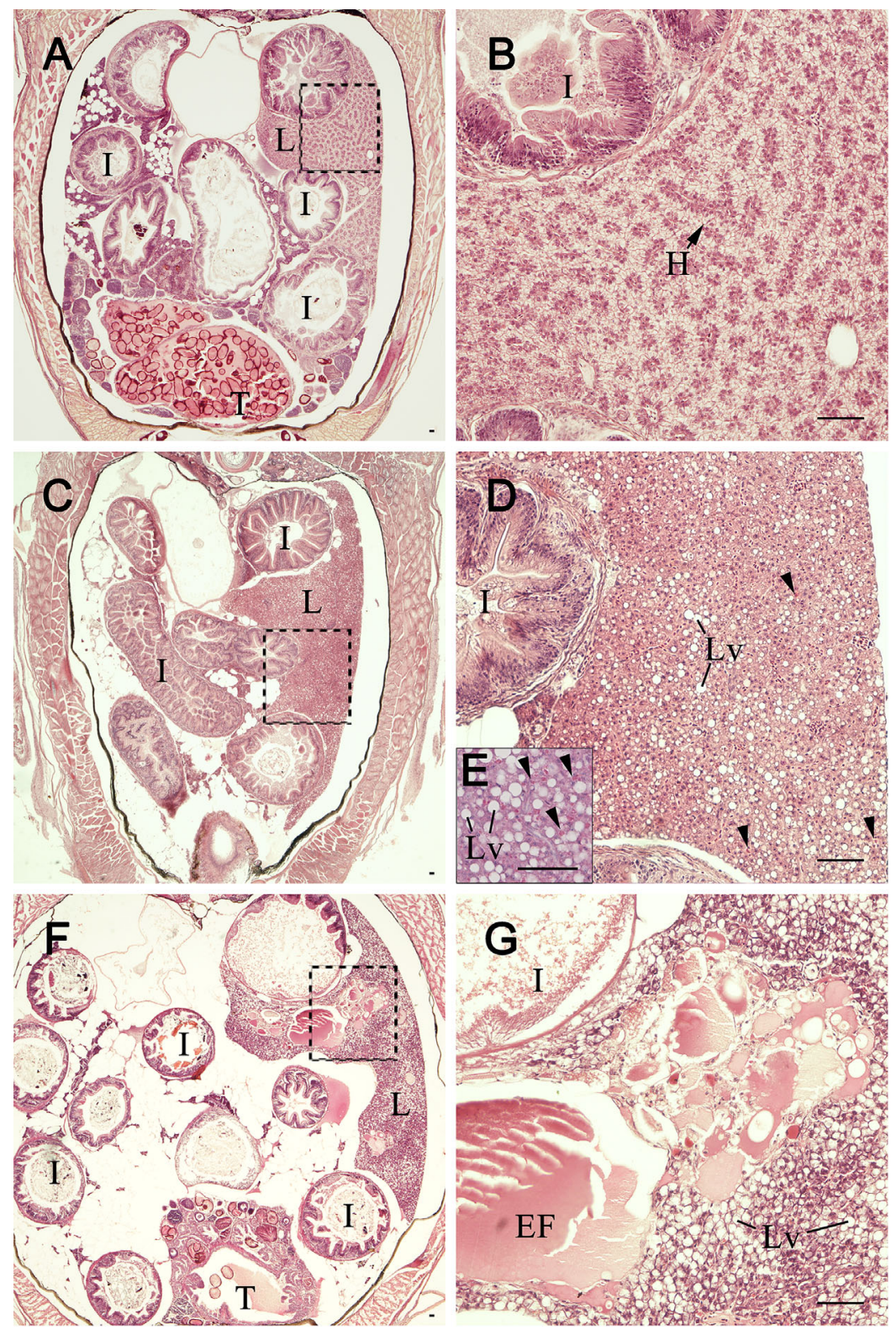

Figure 4. Liver histology of adult male Cnesterodon decemmaculatus exposed to tested $17 \alpha$-ethinylestradiol (EE2) concentrations for 8 wk or 16 wk: (A,B) fish from control ( $0 \mathrm{ng} / \mathrm{L})$ and $20 \mathrm{ng} / \mathrm{L}$ groups after $16 \mathrm{wk}$; (C,D) $100 \mathrm{ng} / \mathrm{L}$ after $16 \mathrm{wk}$ or $200 \mathrm{ng} / \mathrm{L}$ after $8 \mathrm{wk}$; (E) periodic acid-Schiff staining of (D) stage; (F,G) $200 \mathrm{ng} / \mathrm{L}$ after $16 \mathrm{wk}$. Hematoxylin-eosin staining (scale bar $=50 \mu \mathrm{m})$. Arrowheads indicate single-cell necrosis. Dashed squares in panels $(\mathbf{A}, \mathbf{C}, \mathbf{F})$ represent enlarged areas in $(\mathbf{B}, \mathbf{D}, \mathbf{G}) . \mathrm{L}=$ liver; $\mathrm{I}=$ intestine; $\mathrm{T}=$ testis; $\mathrm{H}=$ hepatocyte; $\mathrm{Lv}=$ lipid macrovesicles; $\mathrm{EF}=$ flocculent eosinophilic material.

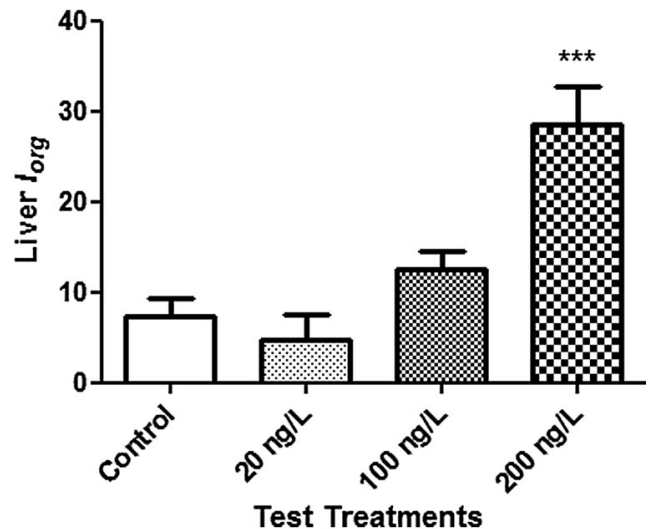

Figure 5. Mean \pm standard error values of the liver organ index for adult male Cnesterodon decemmaculatus after 16 wk of exposure to $17 \alpha$ ethinylestradiol (EE2). Asterisks $(* * *)$ indicate significant differences between test treatments and the control $(p<0.001)$. adult male fish. The induction of intersex gonads by xenoestrogens has been well documented in different gonochoric European (Rutilus rutilus, Gobio gobio, Platichthys flesus, Xiphias gladius) and even South American (Astyanax scabripinnis) fish species [24-27]. Within poeciliids, although some histological alterations were found after the exposure to EDCs [28-30], only intersex induction was previously reported in $G$. affinis, but exposed to the androgen 17 $\beta$-trenbolone [12]. Thus, considering available literature, the present study would be the first report of estrogen-induced intersex in poeciliids worldwide, and it would suggest that this response could also be expected in other species of the family.

Liver damage, indicated by the organ index, was another important response induced by EE2 in adult male $C$. decemmaculatus that was elicited in a concentration-dependent way. Observed alterations started with a slight macrovesicular steatosis and single-cell necrosis (i.e., isolated apoptotic cells) and progressed to a more pronounced macrovesicular steatosis 
Table 3. NOEC and LOEC values estimated for assessed endpoints in adult male Cnesterodon decemmaculatus exposed to EE2

\begin{tabular}{lcccccc}
\hline & \multicolumn{2}{c}{8 wk } & & \multicolumn{2}{c}{$16 \mathrm{wk}$} \\
\cline { 2 - 3 } \cline { 5 - 7 } & NOEC & LOEC & & NOEC & LOEC \\
\hline Condition factor $(K)$ & 200 & ATC & & 20 & 100 \\
Intersex fish (\%) & 20 & 100 & & 20 & 100 \\
Liver organ index $\left(I_{\text {org }}\right)$ & NA & NA & & 100 & 200 \\
\hline
\end{tabular}

NOEC $=$ no-observed-effect concentration; LOEC $=$ lowest-observed-effect concentration; EE2 $=17 \alpha$-ethinylestradiol; $\mathrm{ATC}=$ above tested concentrations; $\mathrm{NA}=$ not assessed.

with cystic degeneration in several sectors of the organ filled with a flocculent eosinophilic material. Steatosis induced by EE2 was previously reported in juvenile male Etheostoma caeruleum [28] and male Rhamdia quelen exposed to $17 \beta$ estradiol (E2) [29]. In addition, hepatocyte apoptosis (considered a form of single-cell necrosis) was found to be induced by EE2 in Oryzias latipes and Chalcalburnus tarichi [30,31]. Degeneration and necrosis of hepatocytes was also observed in the liver of rats fed high concentrations of EE2 [32]. According to those studies, increased lipid content could be explained as estrogenically induced synthesis of lipoproteins involved in vitellogenin and egg yolk production. In addition, single-cell necrosis (i.e., apoptosis) has been interpreted as direct hepatotoxicity of the EE2 itself. Cyst degeneration was not previously reported in EE2-treated fish, such effect was described in rats exposed to other kinds of xenobiotics; nevertheless, the pathogenesis is not fully understood. It could occur as an indirect consequence of EE2-induced synthesis and abnormal accumulation of vitellogenin; however, further studies will be necessary to explain such histopathology.

Condition factor was another interesting biological parameter that was affected at the highest tested concentration of EE2. Such a response observed in $C$. decemmaculatus seems to be somewhat specific and probably is not generalizable to other fish species because loss of weight and condition have been reported in most studies conducted with other fish species exposed to EE2 $[33,34]$. The increase in the condition of exposed male $C$. decemmaculatus could be attributable to the lipid buildup in the liver that has been previously mentioned. In contrast to the usual interpretation, in this case the increase in the condition factor should be understood as fish health impairment (fat and ill fish).

Among all studied biological responses, the most unexpected results were those related to the gonopodium morphology. According to the findings of the present study, the complete developed gonopodium of the adult male $C$. decemmaculatus seems to be entirely insensitive, even under exposure to relatively high estrogen concentrations. Development of the gonopodium in other poeciliid species has been found to be hormonally regulated [7,35]. Consequently, several studies have exploited such characteristics of the anal fin to assess effects of EDCs. For example, the androgen receptor-induced sonic hedgehog (Shh) gene has been reported to be involved in the development of the gonopodium, and exposure to an androgen agonist has shown the ability to modulate this process [7]. Although less studied, gonopodium development also was found to be disrupted by the exposure to estrogens. Both EE2 and E2 have impaired gonopodium development, length, and elongation in juvenile males of Gambusia affinis and Gambusia holbrooki $[10,11]$. Conversely, no effects have been found in the gonopodium when adult male G. affinis were exposed to E2 [36]. Taken together, these results would indicate that the exposure-time window seems to be critical for responses at the gonopodium level in poeciliids and that, once developed, the gonopodium becomes insensitive to estrogens.

From the environmental perspective, ecotoxicological endpoints such as the NOEC and the LOEC are useful parameters for assessing the potential risk of pollutants to aquatic ecosystems. Intersex induction has presented the most sensitive NOEC and LOEC for the estimated biological endpoints, regarding both exposure time and concentration, with values of $20 \mathrm{ng} / \mathrm{L}$ and $100 \mathrm{ng} / \mathrm{L}$, respectively, after $8 \mathrm{wk}$ of exposure. The concentrations of EE2 reported for wastewater effluents and receiving waters among the distribution area of $C$. decemmaculatus in Argentina were between $187 \mathrm{ng} / \mathrm{L}$ and $43 \mathrm{ng} / \mathrm{L}$, respectively [19]. In addition, maximum reported levels in surface waters of other Latin American countries such as Brazil were $54.0 \mathrm{ng} / \mathrm{L}$ and $63.8 \mathrm{ng} / \mathrm{L}$ [37]. Thus, one could expect to find externally normal adult male $C$. decemmaculatus but with testis-ova in areas close to receiving wastewater discharges.

In conclusion, the present study shows for the first time that the gonad and the liver but not the gonopodium of adult male $C$. decemmaculatus are responsive to EE2. However, only the testes seem to be sensitive enough to be affected at environmental concentrations usually found next to wastewater discharges.

Acknowledgment-The present research was supported by INTA (PNNAT 1128042) and ANPCyT (PICT 1383, 1690, and 2619), Argentina. The authors declare no conflict of interest.

Data availability-Data can be provided upon request from the corresponding author (pcarriquiriborde@gmail.com).

\section{REFERENCES}

1. Owen R, Jobling S. 2012. Environmental science: The hidden costs of flexible fertility. Nature 485:441.

2. Kidd KA, Blanchfield PJ, Mills KH, Palace VP, Evans RE, Lazorchak JM, Flick RW. 2007. Collapse of a fish population after exposure to a synthetic estrogen. Proc Natl Acad Sci U S A 104:8897-8901.

3. Ankley GT, Bencic DC, Breen MS, Collette TW, Conolly RB, Denslow ND, Edwards SW, Ekman DR, Garcia-Reyero N, Jensen KM, Lazorchak JM, Martinović D, Miller DH, Perkins EJ, Orlando EF, Villeneuve DL, Wang RL, Watanabe KH. 2009. Endocrine disrupting chemicals in fish: Developing exposure indicators and predictive models of effects based on mechanism of action. Aquat Toxicol 92:168-178.

4. Ankley GT, Johnson RD. 2004. Small fish models for identifying and assessing the effects of endocrine-disrupting chemicals. ILAR J 45:469-483.

5. Mills LJ, Chichester C. 2005. Review of evidence: Are endocrinedisrupting chemicals in the aquatic environment impacting fish populations? Sci Total Environ 343:1-34.

6. Hutchinson TH, Yokota H, Hagino S, Ozato K. 2003. Development of fish tests for endocrine disruptors. Pure and Applied Chemistry 75:2343-2353.

7. Ogino Y, Katoh H, Yamada G. 2004. Androgen dependent development of a modified anal fin, gonopodium, as a model to understand the mechanism of secondary sexual character expression in vertebrates. FEBS Lett 575:119-126.

8. Angus RA, McNatt HB, Howell WM, Peoples SD. 2001. Gonopodium development in normal male and 11-ketotestosterone-treated female mosquitofish (Gambusia affinis): A quantitative study using computer image analysis. Gen Comp Endocrinol 123:222-234.

9. Brockmeier EK, Ogino Y, Iguchi T, Barber DS, Denslow ND. 2013. Effects of $17 \beta$-trenbolone on Eastern and Western mosquitofish (Gambusia holbrooki and G. affinis) anal fin growth and gene expression patterns. Aquat Toxicol 128-129:163-170.

10. Angus RA, Stanko J, Jenkins RL, Watson RD. 2005. Effects of $17 \alpha-$ ethynylestradiol on sexual development of male western mosquitofish (Gambusia affinis). Comp Biochem Physiol C 140:330-339. 
11. Doyle CJ, Lim RP. 2002. The effect of $17 \beta$-estradiol on the gonopodial development and sexual activity of Gambusia holbrooki. Environ Toxicol Chem 21:2719-2724.

12. Sone K, Hinago M, Itamoto M, Katsu Y, Watanabe H, Urushitani H, Tooi O, Guillette Jr LJ, Iguchi T. 2005. Effects of an androgenic growth promoter $17 \beta$-trenbolone on masculinization of mosquitofish (Gambusia affinis affinis). Gen Comp Endocrinol 143:151-160.

13. Dreze V, Monod G, Cravedi JP, Biagianti-Risbourg S, Le Gac F. 2000. Effects of 4-nonylphenol on sex differentiation and puberty in mosquitofish (Gambusia holbrooki). Ecotoxicology 9:93-103.

14. Hrbek T, Seckinger J, Meyer A. 2007. A phylogenetic and biogeographic perspective on the evolution of poeciliid fishes. Mol Phylogenet Evol 43:986-998.

15. Vera Candioti J, Soloneski S, Larramendy ML. 2010. Genotoxic and cytotoxic effects of the formulated insecticide Aficida ${ }^{B}$ on Cnesterodon decemmaculatus (Jenyns, 1842) (Pisces: Poeciliidae). Mutat Res-Gen Tox En 703:180-186.

16. Carriquiriborde P, Díaz J, Mugni H, Bonetto C, Ronco AE. 2007. Impact of cypermethrin on stream fish populations under field-use in biotech-soybean production. Chemosphere 68:613-621.

17. Lucinda PHF. 2005. Systematics of the genus Cnesterodon Garman, 1895 (Cyprinodontiformes: Poeciliidae: Poeciliinae). Neotropical Ichthyology 3:259-270.

18. Parenti LR, Lo Nostro FL, Grier HJ. 2010. Reproductive histology of Tomeurus gracilis Eigenmann, 1909 (Teleostei: Atherinomorpha: Poeciliidae) with comments on evolution of viviparity in atherinomorph fishes. J Morphol 271:1399-1406.

19. Valdés M, Marino D, Wunderlin D, Somoza G, Ronco A, Carriquiriborde P. 2015. Screening concentration of E1, E2 and EE2 in sewage effluents and surface waters of the "Pampas" region and the "Río de la Plata" estuary (Argentina). Bull Environ Contam Toxicol 94:29-33.

20. Chalde T, Fernández DA, Cussac VE, Somoza GM. 2011. The effect of rearing temperature in larval development of pejerrey, Odontesthes bonariensis: Morphological indicators of development. Neotropical Ichthyology 9:747-756.

21. Bernet D, Schmidt H, Meier W, Burkhardt-Holm P, Wahli T. 1999. Histopathology in fish: Proposal for a protocol to assess aquatic pollution. J Fish Dis 22:25-34.

22. Levin S, Bucci TJ, Cohen SM, Fix AS, Hardisty JF, Legrand EK, Maronpot RR, Trump BF. 1999. The nomenclature of cell death: Recommendations of an ad hoc committee of the Society of Toxicologic Pathologists. Toxicol Pathol 27:484-490.

23. Thoolen B, Maronpot RR, Harada T, Nyska A, Rousseaux C, Nolte T, Malarkey DE, Kaufmann W, Küttler K, Deschl U, Nakae D, Gregson R, Vinlove MP, Brix AE, Singh B, Belpoggi F, Ward JM. 2010. Proliferative and nonproliferative lesions of the rat and mouse hepatobiliary system. Toxicol Pathol 38:5S-81S.

24. Rodgers-Gray TP, Jobling S, Kelly C, Morris S, Brighty G, Waldock MJ, Sumpter JP, Tyler CR. 2001. Exposure of juvenile roach (Rutilus rutilus) to treated sewage effluent induces dose-dependent and persistent disruption in gonadal duct development. Environ Sci Technol 35:462-470.

25. Nolan M, Jobling S, Brighty G, Sumpter JP, Tyler CR. 2001. A histological description of intersexuality in the roach. $J$ Fish Biol 58:160-176.

26. Kirby MF, Allen YT, Dyer RA, Feist SW, Katsiadaki I, Matthiessen P, Scott AP, Smith A, Stentiford GD, Thain JE, Thomas KV, Tolhurst L, Waldock MJ. 2004. Surveys of plasma vitellogenin and intersex in male flounder (Platichthys flesus) as measures of endocrine disruption by estrogenic contamination in United Kingdom estuaries: Temporal trends, 1996 to 2001. Environ Toxicol Chem 23:748-758.

27. Sá MdFPd, Fragoso-Moura EN, Fenerich-Verani N, Ferro DAdM. 2008. Occurrence of intersexuality in "Lambaris", Astyanax scabripinnis (Jenyns, 1842), small characids from the Brazilian streams. Braz Arch Biol Technol 51:315-322.

28. Elias EE, Kalombo E, Mercurio SD. 2007. Tamoxifen protects against $17 \alpha$-ethynylestradiol-induced liver damage and the development of urogenital papillae in the rainbow darter (Etheostoma caeruleum). Environ Toxicol Chem 26:1879-1889.

29. Costa DDM, Neto FF, Costa MDM, Morais RN, Garcia JRE, Esquivel BM, Ribeiro CAO. 2010. Vitellogenesis and other physiological responses induced by $17-\beta$-estradiol in males of freshwater fish Rhamdia quelen. Comp Biochem Physiol C 151:248-257.

30. Kaptaner B, Ünal G. 2011. Effects of $17 \alpha$-ethynylestradiol and nonylphenol on liver and gonadal apoptosis and histopathology in Chalcalburnus tarichi. Environ Toxicol 26:610-622.

31. Weber LP, Balch GC, Metcalfe CD, Janz DM. 2004. Increased kidney, liver, and testicular cell death after chronic exposure to $17 \alpha$ ethinylestradiol in medaka (Oryzias latipes). Environ Toxicol Chem 23:792-797.

32. Pandey G, Pandey SP, Sharma M. 2011. Experimental hepatotoxicity produced by ethinyl estradiol. Toxicol Int 18:160-162.

33. Metcalfe CD, Metcalfe TL, Kiparissis Y, Koenig BG, Khan C, Hughes RJ, Croley TR, March RE, Potter T. 2001. Estrogenic potency of chemicals detected in sewage treatment plant effluents as determined by in vivo assays with Japanese medaka (Oryzias latipes). Environ Toxicol Chem 20:297-308.

34. Pawlowski S, van Aerle R, Tyler CR, Braunbeck T. 2004. Effects of $17 \alpha$-ethinylestradiol in a fathead minnow (Pimephales promelas) gonadal recrudescence assay. Ecotoxicol Environ Safe 57:330-345.

35. Offen N, Kang JH, Meyer A, Begemann G. 2013. Retinoic acid is involved in the metamorphosis of the anal fin into an intromittent organ, the gonopodium, in the green swordtail (Xiphophorus hellerii). PLoS One 8:e77580.

36. Doyle CJ, Lim RP. 2005. Sexual behavior and impregnation success of adult male mosquitofish following exposure to $17 \beta$-estradiol. Ecotoxicol Environ Safe 61:392-397.

37. Moreira M, Aquino S, Coutrim M, Silva J, Afonso R. 2011. Determination of endocrine-disrupting compounds in waters from Rio das Velhas, Brazil, by liquid chromatography/high resolution mass spectrometry (ESI-LC-IT-TOF/MS). Environ Technol 32:1409-1417. 